\title{
METODE ISOLASI DEOXYRIBO NUCLEIC ACID BAKTERI DARI ORGAN IKAN NILA (Oreochromis niloticus) UNTUK DIAGNOSA Streptococcociasis DENGAN TEKNIK POLYMERASE CHAIN REACTION
}

\author{
Lila Gardenia dan Isti Koesharyani \\ Pusat Penelitian dan Pengembangan Perikanan Budidaya \\ Jl. Ragunan 20, Pasar Minggu, Jakarta Selatan 12540 \\ E-mail: lila_abimanyu@yahoo.com
}

(Naskah diterima: 9 Agustus 2011; Disetujui publikasi: 3 November 2011)

\begin{abstract}
ABSTRAK
Streptococcus sp. menyebabkan wabah penyakit dan menimbulkan kematian massal pada beberapa jenis ikan di seluruh dunia dengan angka kerugian yang ditimbulkannya berkisar 150 juta US\$ per tahun. Streptococcus agalactiae merupakan salah satu bakteri penyebab Streptococcocis pada ikan nila (Oreochromis niloticus). Saat ini diagnosa agen penyebab penyakit bakteri tersebut dapat dilakukan dengan teknik PCR (Polymerase Chain Reaction) menggunakan pasangan primer spesifik (Sdi252Sdi61), namun pada umumnya ekstraksi dilakukan melalui proses mengisolasi bakteri dari organ terinfeksi, menumbuhkan pada media agar, pemurnian isolat dan terakhir isolasi DNA. Sedangkan isolasi DNA bakteri langsung dari organ yang terinfeksi dapat mempersingkat waktu diagnosa agen penyakit tersebut. Tujuan penelitian ini adalah untuk memperoleh metode ekstraksi yang dapat mengisolasi DNA bakteri secara langsung dari organ ikan yang terinfeksi (otak, hati, limfa, dan ginjal). Metode yang digunakan adalah pemanasan, ekstraksi DNA secara kimiawi dengan DNAzol reagent dan dengan mini column QIAamp DNA Mini Kit. Dari hasil penelitian menunjukkan bahwa metode pemanasan, DNAzol reagent dan QIAamp DNA Mini Kit masing- masing menghasilkan band positif sebesar $82 \%$ 64\% dan $100 \%$ Limfa dapat digunakan untuk mengisolasi DNA Streptococcus agalactiae secara langsung dengan menggunakan ketiga macam metode ekstraksi, namun QIAamp DNA Mini Kit menghasilkan DNA yang lebih bersih dengan tingkat kemurnian yang tinggi. Isolasi langsung dari organ mempercepat proses identifikasi bakteri.
\end{abstract}

KATA KUNCI: Streptococcus agalactiae, ekstraksi DNA, bakteri, PCR

\begin{abstract}
Methods of bacterial Deoxyribo Nucleic Acid isolation from tissue organs of nile tilapia (Oreochromis niloticus) for Polymerase Chain Reaction diagnosis of Streptococcociasis. By: Lila Gardenia and Isti Koesharyani
\end{abstract}

Streptococcus sp. have caused numerous outbreaks of disease and caused mass mortality of several cultured fish species throughout the world resulting in severe economic losses of $\$ 150$ million annually. Streptococcus agalactiae is one of the bacteria that cause Streptococcocis in nile tilapia (Oreochromis niloticus). Currently, the detection of the causative agents of the bacterial diseases can be carried out by PCR (Polymerase Chain Reaction) using specific primer pairs (Sdi252Sdi61). However, the extraction of bacteria is done through several isolation processes 
which are isolating the bacteria from infected organs tissue, growing on agar plates, isolation and purification of the bacterial isolates before proceeding to the DNA extraction. An approach of isolating the bacterial DNA directly from the infected tissues can greatly reduce the lenght of detection process. The aim of this study was to obtain the extraction method that can isolate bacterial DNA directly from organ tissues of infected fish (brain, liver, spleen and kidney). The methods used were heating, chemical DNA extraction with DNAzol reagent and mini-column based DNA extraction with QIAamp DNA Mini Kit. The results showed that heating, DNAzol reagent and mini-column based DNA Mini Kit methods, can produced a positive band of $82 \%, 64 \%$ and $100 \%$ respectively. Spleen as the target organ in Streptococcus agalactiae infection can be used in direct isolation of bacterial DNA using all of the extraction methods used in this research. DNA isolated from QIAamp DNA Mini Kit methods is cleaner and has higher level of purification. Isolation of DNA directly from infected organ can shorten the lenght of the bacterial identification process.

\section{KEYWORDS: Streptococcus agalactiae, DNA extraction, bacteria, PCR}

\section{PENDAHULUAN}

Streptococcus spp. menyebabkan wabah penyakit dan menimbulkan kematian massal pada beberapa jenis ikan di seluruh dunia dengan angka kerugian yang ditimbulkannya mencapai 150 juta US\$ per tahun (Klesius et al., 2000). Streptococcocis merupakan penyakit bakterial yang disebabkan oleh infeksi bakteri Streptococcus sp., Lactococcus sp., dan Vagococcus sp. Penyakit ini menyimbulkan banyak kerugian yang disebabkan tingginya tingkat kematian akibat serangan bakteri tersebut hingga 30\% 50\%(Eldar et al., 1995).

Ikan yang terinfeksi bakteri Streptococcus umumnya mengalami infeksi sistemik yang menyerang mata, hati dan limfa. Gejala klinis yang ditimbulkannya antara lain unilateral atau bilateral exopthalmia, pendarahan pada mata, tubuh kehitaman, berenang tidak beraturan, dan pembengkakan pada limfa (Rasheed et al., 1985). Ikan sakit akibat infeksi bakteri tersebut dapat pula memperlihatkan gejala klinis seperti berenang berputar pada permukaan air, bentuk tubuh melengkung (berbentuk huruf " $\mathrm{C}$ "), kelainan pada mata seperti mata keruh, pendarahan intraocular dan periorbital (Evans et al., 2002). Menurut Eldar et al. (1995), gejala yang paling signifikan dari penyakit ini pada ikan adalah septikemia dan meningoencephalitis. Bakteri ini menyerang organ target seperti limfa, hati, dan otak, kemudian menyebar ke ginjal, usus dan jantung (Austin \& Austin, 1999). Limfa tampak membesar dan rusak, hati terlihat pucat dan mengalami nekrosis. Usus mengandung cairan dan pendarahan di beberapa tempat, serta kadang-kadang dijumpai otak berwarna kekuningan dan mengandung banyak bakteri (Kitao, 1993; Austin \& Austin, 1999).

Streptococcus agalactiae merupakan bakteri gram positif berbentuk coccus dengan sifat antara lain katalase negatif, oksidase negatif, hippurate hydrolisis negatif, dan CAMP (Christie, Atkins and Munch- Petersen) positif dimana senyawa ekstraselular dari S. agalactiae berdifusi dan bereaksi dengan beta- hemolysin dari Staphylococcus aureus sehingga menghasilkan daerah lisis yang nyata dan luas pada media agar darah domba.

Saat ini Polymerase Chain Reaction (PCR) telah menjadi metode alternatif yang telah banyak digunakan untuk mengidentifikasi Streptococcus agalactiae. Teknik untuk mendiagnosa penyakit ini telah dikembangkan oleh Berridge et al. (2001), Mata et al. (2004), dan Kawamura et al. (2005). Mereka menghasilkan primer spesies spesifik dengan target 16S- 23S rDNA intergenic spacer region dan 23SrDNA yang spesifik untuk Streptococcus agalactiae. Teknik ini lebih cepat dan akurat dibandingkan metode konvensional seperti uji karakteristik biokimia. Uji karakterisasi fisiologi sering menimbulkan kesulitan dalam mengidentifikasi karena hasilnya dapat berbeda- beda tergantung pada ukuran inokulum, suhu dan lama inkubasi, komposisi media, perbandingan volume terhadap permukaan media, dan kriteria yang digunakan untuk mendefinisikan reaksi positif dan negatif (Holt et al., 1994).

Proses ektraksi pada dasarnya adalah untuk membebaskan DNA dari massa sel dan komponen-komponen lain di dalam sel. Umumnya ekstraksi untuk mengisolasi DNA 
bakteri dilakukan melalui beberapa tahapan seperti mengisolasi bakteri dari organ terinfeksi, menumbuhkan pada media agar, pemurnian isolat dan terakhir dilakukan isolasi DNA. Proses tersebut menyebabkan identifikasi agen penyakit tersebut membutuhkan waktu 2- 3 hari sebelum dilakukan proses PCR. Sedangkan isolasi DNA bakteri langsung dari organ yang terinfeksi dapat mempersingkat waktu diagnosa agen penyakit tersebut. Namun diperlukan metode isolasi DNA bakteri yang baik dan tepat, karena sensitivitas PCR sangat dipengaruhi metode ekstraksi DNA (Sjobring et al.,1990). Tujuan penelitian ini adalah untuk memperoleh metode ekstraksi yang dapat mengisolasi DNA bakteri langsung dari organ yang terinfeksi.

\section{BAHAN DAN METODE}

Sampel ikan nila (Oreochromis niloticus) berasal dari kasus kematian dengan mortalitas lebih dari 50\%pada tambak bersalinitas rendah di Karawang, Jawa Barat. Ikan nila sakit mengalami gejala Streptococcocis dengan ciriciri berenang berputar dan tidak beraturan, mata menonjol, dan tubuh berwarna kehitaman. Ikan sebanyak 3 ekor dibawa dalam keadaan hidup ke Laboratorium Riset Kesehatan IkanPusat Penelitian dan Pengembangan Perikanan Budidaya, Jakarta dan dilakukan isolasi bakteri dari otak masing- masing ikan (sebagai kontrol). Isolat ditumbuhkan pada media BHIA (Brain Heart Infusion Agar) dan ditumbuhkan di dalam inkubator pada suhu $28^{\circ} \mathrm{C}$ selama $24-48$ jam. Setelah dimurnikan beberapa kali, isolat bakteri (10-20 koloni) diambil menggunakan ose steril dan disimpan dalam $400 \mu \mathrm{L}$ RNAse free water. Sampel jaringan seperti otak, hati, limfa dan ginjal dari setiap ikan sampel, masingmasing disimpan dalam tabung mikro $1.5 \mathrm{~mL}$ berisi $750 \mu \mathrm{L}$ alkohol 95\% Masing-masing sampel jaringan (kurang lebih $75 \mathrm{~g}$ ) diambil dan dihancurkan dengan menggunakan gunting. Jaringan kemudian dibagi ke dalam 3 tabung mikro yang diberi label sesuai dengan jaringan, nomor ikan dan metode ekstraksi yang akan digunakan. DNA bakteri dari isolat maupun jaringan ikan yang digunakan dalam uji PCR ini diekstraksi dengan menggunakan 3 macam metode yaitu dengan pemanasan, DNAzol reagent dan QIAamp DNA Mini Kit (QIAGEN).

\section{Ekstraksi dengan Pemanasan}

Ekstraksi DNA bakteri dari jaringan ikan yang terinfeksi dilakukan RNAse free water sebanyak $300 \mu \mathrm{L}$. Tabung mikro kemudian dipanaskan pada suhu $98^{\circ} \mathrm{C}$ selama 10 menit diatas thermomixer sambil sesekali dikocok menggunakan minimixer. Debris sel dipisahkan dari DNA bakteri dengan cara sentrifugasi pada $8.000 \times$ g selama 10 menit. Cairan bening (supernatant) diambil sebanyak $300 \mu \mathrm{l}$ dan dipindahkan ke dalam tabung mikro baru dan disimpan pada suhu $-20^{\circ} \mathrm{C}$ sampai digunakan. DNA kemudian disimpan pada $-20^{\circ} \mathrm{C}$ sampai akan digunakan dalam proses amplifikasi.

\section{Ekstraksi dengan DNAzol Reagent (Invitrogen)}

Ke dalam tabung mikro 1,5 mL yang telah berisi sampel jaringan ( $25 \mathrm{mg}$ ), ditambahkan $500 \mu \mathrm{L}$ DNAzol lalu dihancurkan dengan menggunakan penggerus. Suspensi kemudian disentrifugasi pada $12.000 \mathrm{rpm}$ selama 10 menit. Supernatan yang diperoleh Ialu dipindahkan ke tabung mikro $1,5 \mathrm{~mL}$ baru yang telah berisi $100 \%$ Ethanol sebanyak 500 $\mu \mathrm{L}$. Agar homogen larutan dibolak-balik sebanyak 5 kali, kemudian diinkubasi pada suhu ruang selama 1- 3 menit. Sentrifugasi dilakukan kembali pada 8.000 rpm selama 2- 3 menit dan supernatan yang dihasilkan dibuang. Pellet DNA lalu ditambahkan 95\% Ethanol sebanyak $500 \mu \mathrm{L}$, dibolak- balik dan selanjutnya disentrifugasi pada $8.000 \mathrm{rpm}$ selama 2- 3 menit. Supernatan kembali dibuang, kemudian segera ditambahkan TE (Tris- EDTA) buffer sebanyak $100 \mu \mathrm{L}$. DNA kemudian disimpan pada $-20^{\circ} \mathrm{C}$ sampai akan digunakan dalam proses amplifikasi .

\section{Ekstraksi dengan QIAamp DNA Mini Kit (QIAGEN)}

Ke dalam tabung mikro 1,5 mL yang telah berisi sampel jaringan ( $25 \mathrm{mg}$ ), ditambahkan $180 \mu \mathrm{L}$ larutan ATL (Tissue Lysis Buffer) dan 20 $\mu \mathrm{L}$ Proteinase- K. Tabung mikro lalu dikocok menggunakan minimixer dan diinkubasi pada suhu $56^{\circ} \mathrm{C}$ selama $1-3 \mathrm{jam} /$ overnight sampai lisis, kemudian di "spindown" selama beberapa detik. Sebanyak $200 \mu \mathrm{L}$ larutan AL (Lysis Buffer) dimasukkan ke dalam tabung mikro, lalu dikocok menggunakan minimixer selama 15 detik dan diinkubasi pada suhu $70^{\circ} \mathrm{C}$ selama 10 menit. Tabung di "spindown" selama beberapa detik, kemudian ditambahkan 200 $\mu \mathrm{L}$ Ethanol $100 \%$ diaduk dan dikocok menggunakan minimixer kembali selama 15 detik. Tabung kembali di "spindown"selama beberapa 
detik. Cairan putih bening akan terbentuk setelah penambahan ethanol, kemudian semua cairan dipindahkan secara hati- hati ke dalam $2 \mathrm{~mL}$ minispin-column dan collection tube yang tersedia, lalu ditutup dengan baik dan disentrifugasi pada $6.000 \mathrm{~g}(8.000 \mathrm{rpm})$ selama 1 menit. Collection tube yang berisi cairan dibuang, kemudian minispin-column ditempatkan pada collection tube baru, Ialu ditambahkan $500 \mu \mathrm{L}$ larutan AW- 1 (column wash buffer-1) dan disentrifugasi pada 8.000 rpm selama 1 menit. Collection tube yang berisi cairan dibuang. Minispin column kemudian ditempatkan pada collection tube baru, lalu ditambahkan $500 \mu \mathrm{L}$ larutan AW- 2 (column wash buffer-2) dan disentrifugasi pada $14.000 \mathrm{rpm}$ selama 3 menit. Collection tube yang berisi cairan dibuang kembali. Minispin column dipindahkan pada 1,5 mL mikrotube bersih/ baru lalu ditambahkan secara hati- hati $200 \mu \mathrm{L}$ Buffer AE (Elution Buffer) atau Destilated water. Setelah didiamkan selama 1- 3 menit kemudian disentrifugasi pada $8.000 \mathrm{rpm}$ selama 1 menit. DNA kemudian disimpan pada $-20^{\circ} \mathrm{C}$ sampai akan digunakan dalam proses amplifikasi.

\section{Primer dan Amplifikasi PCR}

Pasangan primer oligonukleotida yang digunakan untuk mendeteksi bakteri pathogen Streptococcus difficilis (Mata et al., 2004) sebagai berikut: Sdi 61 : 5'AGGAAACCTGCCATTTGCG- 3' Sdi 252 : 5'CAATCTATTTCTAGATCGTGG- 3' dengan target gen 165 intergenic spacer dengan panjang 192 bp. Primer yang digunakan dalam proses PCR ini disintesa oleh Alpha DNA (Montreal, Quebec).

Proses amplifikasi PCR dilakukan di dalam campuran reaksi dengan volume $25 \mathrm{ml}$ per sampel sebagai berikut: master mix GoTa ${ }^{\circledR}$ Green (Promega, Madison WI USA) sebanyak $12,5 \mu \mathrm{L}$, nuclease free water sebanyak 8,5 $\mu \mathrm{L}$, primer (reverse dan forward) masing- masing sebanyak $1 \mu \mathrm{L}$ dan template DNA sebanyak $2 \mu \mathrm{L}$. Amplifikasi dilakukan menggunakan thermal cycler MJ. Research dengan program siklus amplifikasi sebagai berikut: setelah tahap denaturasi awal pada suhu $94^{\circ} \mathrm{C}$ selama 2 menit, kemudian lakukan 25 kali siklus denaturasi pada $92^{\circ} \mathrm{C}$ selama 1 menit, annealing pada $55^{\circ} \mathrm{C}$ selama 1 menit, dan elongasi pada $72^{\circ} \mathrm{C}$ selama 90 detik. Terakhir dilakukan proses elongasi akhir pada $72^{\circ} \mathrm{C}$ selama 5 menit. Sebagai negatif kontrol (no template DNA) digunakan RNAse free water.

\section{Elektroforesis}

Hasil amplifikasi dideteksi dengan mengelektrophoresis masing-masing amplikon sebanyak $10 \mu \mathrm{L}$ pada $1,5 \%$ gel agarose di dalam buffer $1 x$ Tris- acetate- EDTA (220 V selama 25 menit). Pewarnaan DNA dilakukan dengan perendaman gel dalam Iarutan ethidium bromide $(0,5 \mu \mathrm{g}$ per $100 \mathrm{~mL}$ TAE buffer) selama 15 menit dan hasilnya didokumentasikan dengan kamera polaroid.

\section{Penghitungan Konsentrasi DNA dengan NanoDrop}

DNA dihitung konsentrasinya dengan meneteskan $1 \mu \mathrm{L}$ setiap sampel DNA dari masing-masing metode ekstraksi pada alat Nanodrop (Thermo Scientific) yang dihubungkan langsung dengan komputer. Software yang telah tersedia akan membaca konsentrasi asam nukleatnya dengan satuan $\mathrm{ng} / \mu \mathrm{L}$. Absorbansi dibaca pada tiga panjang gelombang yaitu $230 \mathrm{~nm}, 260 \mathrm{~nm}$, dan 280 $\mathrm{nm}$. Konsentrasi DNA diperoleh dari perkalian nilai absorbansi $260 \mathrm{~nm}$, faktor pengenceran, dan konversi $O D_{260}$ sebesar $50 \mathrm{ug} / \mathrm{mL}$.

\section{HASIL DAN BAHASAN}

Diagnosa PCR menggunakan primer spesifik untuk Streptococcus agalactiae yaitu Sdi252 dan Sdi62 (Mata et al., 2004) yang mengamplifikasikan gen 16S- 23S RNA intergenic spacer. Hasil amplifikasi tersebut akan menghasilkan pita positif pada berat molekul target (192 bp) pada jaringan yang terinfeksi bakteri.

Uji PCR dari DNA hasil ekstraksi menggunakan metode pemanasan (Gambar 1) memperlihatkan pita positif pada sebagian besar organ. Walaupun terdapat beberapa pita positif yang sangat tipis, namun masih dapat teramati dengan cukup baik di bawah UV transiluminator.

Hasil uji PCR sampel jaringan yang diekstraksi dengan menggunakan metode DNAzol reagent dan metode mini-column DNA kit dapat diamati pada Gambar 2 dan 3. Dari hasil dokumentasi tersebut teramati otak dan hati sering mengalami hasil false negatif dan juga menghasilkan pita positif yang sangat tipis. 


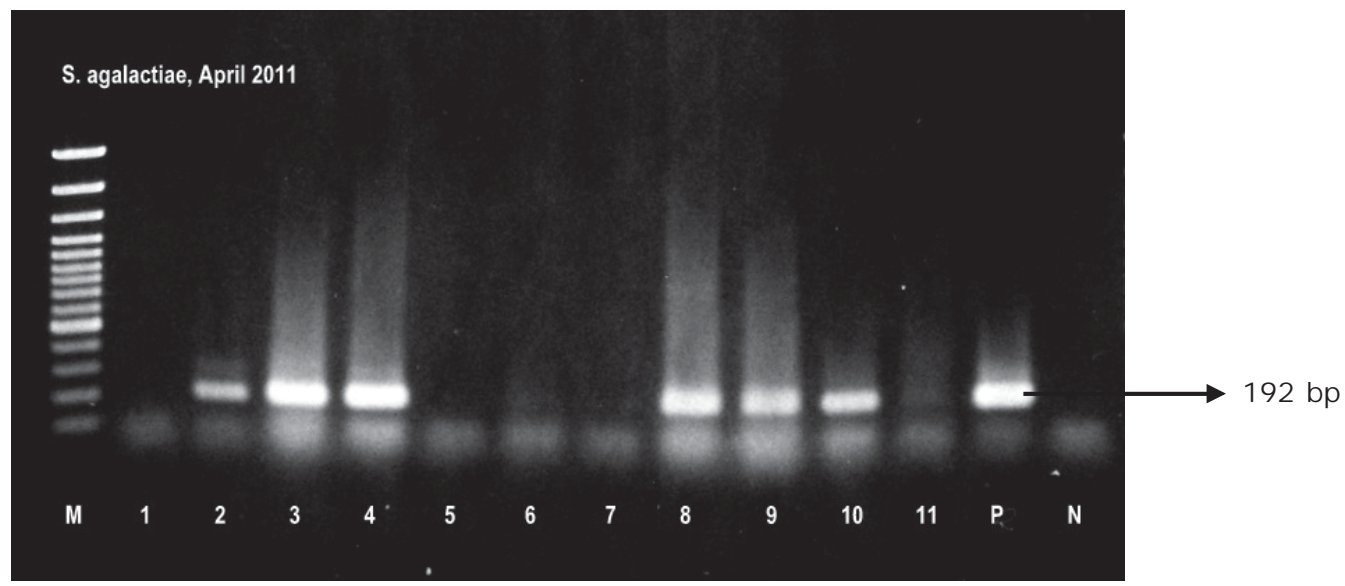

Gambar 1. Hasil deteksi PCR S. agalactiae dari jaringan ikan nila menggunakan metode pemanasan. M. Marker 100 bp ladder plus (Fermentas), No. 1- 3, jaringan ikan nila- 1 (otak, hati, dan limfa). No. 4- 7, jaringan ikan nila- 2 (otak, hati, limfa dan ginjal). No. 8- 11, jaringan ikan nila- 3 (otak, limfa, ginjal, dan hati). P. Positif kontrol dan N. Negatif kontrol

Figure 1. The result of PCR detection of $\mathbf{S}$. agalactiae from tilapia organ tissue using heating method. M. Marker 100 bp ladder plus (Fermentas), No. 1-3, organs of fish-1 (brain, liver, and spleen). No. 4-7, organs of fish-2 (brain, liver, spleen and kidneys). No. 8-1 1, organs of fish-3 (brain, spleen, kidney, and liver). P. Positive control and N. Negative control

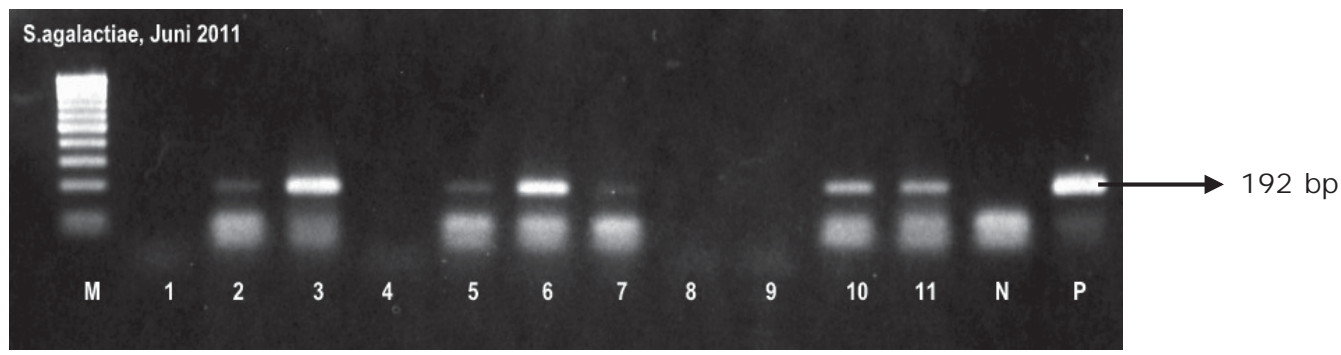

Gambar 2. Hasil deteksi PCR S. agalactiae dari jaringan ikan nila dengan metode DNAzol reagent. M. Marker 100 bp ladder plus (Fermentas), No. 1- 3, jaringan ikan nila- 1 (otak, hati dan limfa). No. 4- 7, jaringan ikan nila- 2 (otak, hati, limfa dan ginjal). No. 8- 11, jaringan ikan nila- 3 (otak, hati, ginjal, dan limfa). P. Positif kontrol dan N. Negatif kontrol

Figure 2. The result of PCR detection of S. agalactiae from tilapia organ tissues using DNAzol reagent method. M. Marker 100 bp ladder plus (Fermentas), No. 1-3, organ tissues of fish-1 (brain, liver and spleen). No. 4-7, organ tissues of fish-2 (brain, liver, spleen, and kidneys). No. 8-1 1, organ tissue of fish-3 (brain, liver, kidney, and spleen). P. Positive control and N. Negative control

Perbandingan hasil PCR dari beberapa metode ekstraksi yang digunakan dalam penelitian ini dapat dilihat pada Tabel 1. Minicolumn DNA kit menghasilkan hasil uji yang $100 \%$ positif, sedangkan kedua metode lainnya masing- masing hanya menghasilkan pita positif sebesar $82 \%$ dan $64 \%$ Metode tersebut merupakan metode isolasi DNA yang menggunakan spin column dan membran silika gel yang akan menghasilkan DNA yang bersih dari kontaminan dan inhibitor. DNA berikatan dengan silika gel pada membran, sedangkan kontaminan lainnya terbuang melewati poripori membran. Hal ini menyebabkan proses 


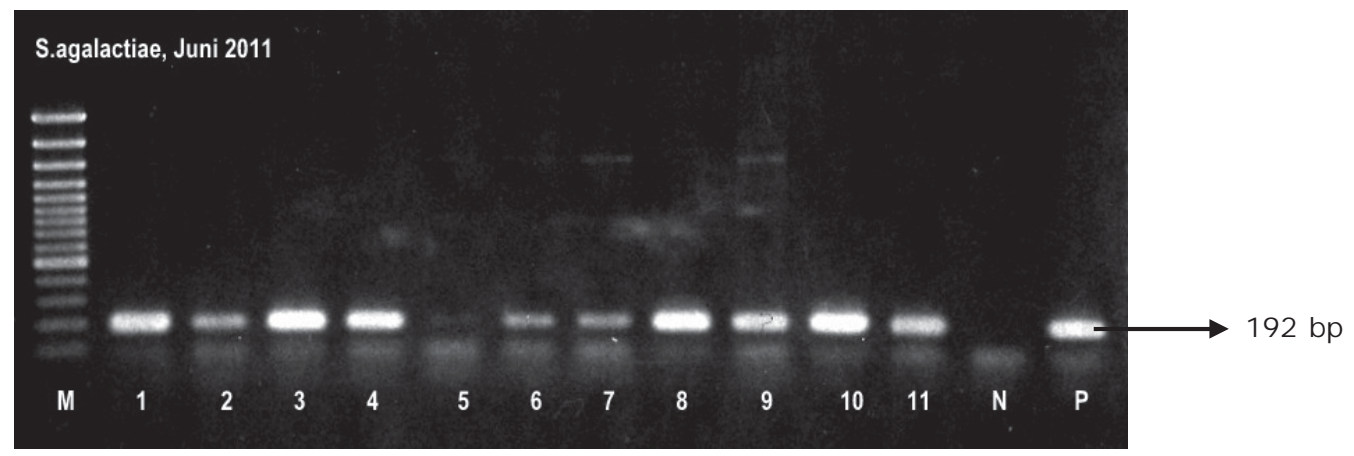

Gambar 3. Hasil deteksi PCR S. agalactiae dari jaringan ikan nila dengan mini-column QIAamp DNA mini kit. M. Marker 100 bp ladder plus (Fermentas), No. 1- 3, jaringan ikan nila- 1 (otak, hati, dan limfa). No. 4- 7, jaringan ikan nila- 2 (otak, hati, limfa, dan ginjal). No. 8- 11, jaringan ikan nila- 3 (otak, limfa, ginjal, dan hati). P. Positif kontrol dan N. Negatif kontrol

Figure 3. The result of PCR detection of S. agalactiae from tilapia organ tissues using minicolumn QIAamp DNA minikit method. M. Marker 100 bp ladder plus (Fermentas), No. 1-3, organ tissues of fish-1 (brain, liver, and spleen). No. 4-7, organ tissues of fish-2 (brain, liver, spleen, and kidneys). No. 8-11, organ tissues of fish-3 (brain, spleen, kidney, and liver). P. Positive control and N. Negative control

Tabel 1. Hasil uji PCR DNA Streptococcus agalactiae dari organ ikan nila menggunakan beberapa metode ekstraksi

Table 1. PCR test of Streptococcus agalactiae DNA from nile tilapia organ tissues by using several extraction methods

\begin{tabular}{llccc}
\hline $\begin{array}{l}\text { Organ } \\
\text { Tissue }\end{array}$ & $\begin{array}{c}\text { Metode 1 } \\
\text { Pemanasan } \\
\text { Heating method }\end{array}$ & $\begin{array}{c}\text { Metode 2 } \\
\text { DNAzol } \\
\text { DNAzol method }\end{array}$ & $\begin{array}{c}\text { Metode 3 } \\
\text { QIAamp Mini kit } \\
\text { QIAmp mini kit method }\end{array}$ \\
\hline Ikan-1 & Otak (Brain) & - & - & + \\
Fish-1 & Hati (Liver) & + & + & + \\
& Limfa (Spleen) & + & + & + \\
Ikan-2 & Otak (Brain) & + & - & + \\
Fish-2 & Hati (Liver) & - & + & + \\
& Ginjal (Kidney) & + & + & + \\
& Limfa (Spleen) & + & + & + \\
Ikan-3 & Otak (Brain) & + & - & + \\
Fish-3 & Hati (Liver) & + & + & + \\
& Ginjal (Kidney) & + & + & $11 / 11=100 \%$ \\
& Limfa (Spleen) & + & $7 / 11=64 \%$ & + \\
\hline \multicolumn{2}{c}{$\begin{array}{c}\text { Persentase } \\
\text { Percentage }\end{array}$} & $9 / 11=82 \%$ & & \\
\hline
\end{tabular}

ekstraksi pada metode ini lebih optimal dan DNA yang dihasilkan lebih bersih dari kontaminan dan inhibitor yang dapat menghambat proses amplifikasi.
DNAzol reagent merupakan metode yang cepat dan mudah dalam mengisolasi DNA. Metode ini menggunakan bahan kimia siap pakai yang dapat digunakan untuk mengisolasi 
genom DNA dari sampel padat dan cairan (tanaman maupun hewan). Namun untuk mengisolasi DNA bakteri (khususnya gram positif) dari jaringan yang terinfeksi, memerlukan modifikasi atau pre-treatment dengan pemanasan atau bahan kimia lain untuk memecahkan atau melisiskan dinding sel bakteri. Hal ini menyebabkan kurang efektifnya reagent tersebut dalam mengisolasi DNA bakteri langsung dari jaringan sehingga hanya $64 \%$ sampel yang positif. Sedangkan metode dengan pemanasan merupakan metode yang sangat sederhana, dengan menggunakan suhu tinggi hingga sel pecah. Metode ini mudah, murah, dan biasa digunakan untuk ekstraksi isolat bakteri dari kultur yang telah murni. Metode ini cukup baik dalam mengisolasi DNA bakteri dalam jaringan sel yang terinfeksi sehingga terdapat 82\%sampel yang menghasilkan pita positif. Namun DNA yang dihasilkan masih mengandung banyak kontaminan dan inhibitor, terutama pada jaringan yang mengandung banyak protein seperti otak dan hati.

Streptococcus agalactiae menyerang organ target seperti limfa, hati, dan otak, kemudian menyebar ke ginjal, usus dan jantung (Austin \& Austin, 1999). Pada penelitian ini isolasi DNA dilakukan dari otak, hati, limfa, dan ginjal. Organ- organ tersebut merupakan organ target Streptococcus agalactiae yang dapat digunakan untuk mendeteksi bakteri tersebut secara langsung, namun hanya limfa yang memperlihatkan hasil yang konsisten dengan menggunakan ketiga macam metode ekstraksi.

Hasil pengukuran DNA dengan menggunakan Nanodrop (Thermo Scientific), terlihat ekstraksi dengan metode DNAzol reagent cenderung memiliki konsentrasi DNA yang hampir sama atau lebih rendah dibandingkan dengan pengukuran dengan mini-column DNA kit (Tabel 2). Tetapi hasil pengukuran DNA yang diektraksi dengan metode pemanasan jauh lebih tinggi. Hal ini dapat disebabkan pada metode pamanasan hanya dilakukan proses pemecahan dinding sel untuk membebaskan isi sel dan sentrifugasi untuk pemisahan eksudat. Tidak ada proses degradasi protein dan RNA menggunakan protease dan RNAse menyebabkan DNA yang dihasilkan masih tercampur. Kelemahan instrumen spektrofotometer UV untuk pengukuran DNA adalah bahwa RNA dan garam-garam yang mengkontaminasi akan terukur juga absorbansinya bersama dengan DNA sehingga menyebabkan hasil yang terukur jauh lebih tinggi pada metode ini dibandingkan kedua metode lainnya. Keakuratan pembacaan alat spektrofotometer terhadap konsentrasi asam nukleat tergantung pada tingkat pemurnian hasil ekstraksi tersebut pada saat pengukuran.

Dalam penelitian ini konsentrasi DNA hasil ekstraksi dari ketiga metode tersebut dilakukan dengan cara spektofotometri. Nukleotida, ssDNA, dan dsDNA diukur akan menunjukkan absorbansi total pada $260 \mathrm{~nm}$. Rasio pada $260 \mathrm{~nm}$ dan $280 \mathrm{~nm}$ digunakan untuk menilai kemurnian DNA. Sampel DNA dapat dikatakan murni apabila berada dalam skala 1,8-2,0. Pada ketiga macam metode, nilai rasio dari asam nukleat yang diekstraksi dengan metode pemanasan terdapat lebih dari $50 \%$ berada di bawah skala kemurnian, sedangkan metode DNAzol reagent kurang lebih $50 \%$ memiliki kemurnian di atas skala rasio yang ditentukan. Hanya metode minicolumn DNA kit yang menghasilkan asam nukleat yang berada dalam skala kemurnian. Terdapat beberapa faktor yang menyebabkan rasio tersebut berubah/ bervariasi, antara lain perubahan $\mathrm{pH}$ pada sampel (Wilfinger et al., 1997) dan komposisi dari lima jenis nukleotida yang terdapat di dalamnya (Leninger, 1975).

Rasio pada $260 \mathrm{~nm}$ dan $230 \mathrm{~nm}$ juga dapat digunakan sebagai pengukuran tingkat kemurnian asam nukleat. Nilai rasio tersebut lebih tinggi dibandingkan nilai rasio pada 260 $\mathrm{nm}$ dan $280 \mathrm{~nm}$. Nilai rasio pada $260 \mathrm{~nm}$ dan $230 \mathrm{~nm}$ dikatakan murni apabila berada dalam skala 2,0-2,2. Nilai rasio pada hasil ekstraksi menggunakan metode pemanasan dan metode DNAzol reagent berada di bawah skala murni, hal ini menunjukkan adanya kontaminasi protein, fenol, garam atau kontaminan lainnya yang diabsorbsi pada $230 \mathrm{~nm}$ (Anonim, 2008). Metode DNAzol reagent mengandung larutan guanidine detergent sebagai bahan pelisis yang menghidrolisis RNA dan mempresipitasi DNA. Larutan tersebut ikut terabsorbsi pada $230 \mathrm{~nm}$ sehingga nilai rasionya menjadi rendah. Selain itu nilai rasio yang rendah dapat disebabkan oleh adanya zat EDTA, karbohidrat, dan fenol.

\section{KESIMPULAN DAN SARAN}

Limfa dapat digunakan untuk mengisolasi DNA Streptococcus agalactiae secara langsung dengan menggunakan ketiga macam metode ekstraksi, namun QIAamp DNA Mini Kit 


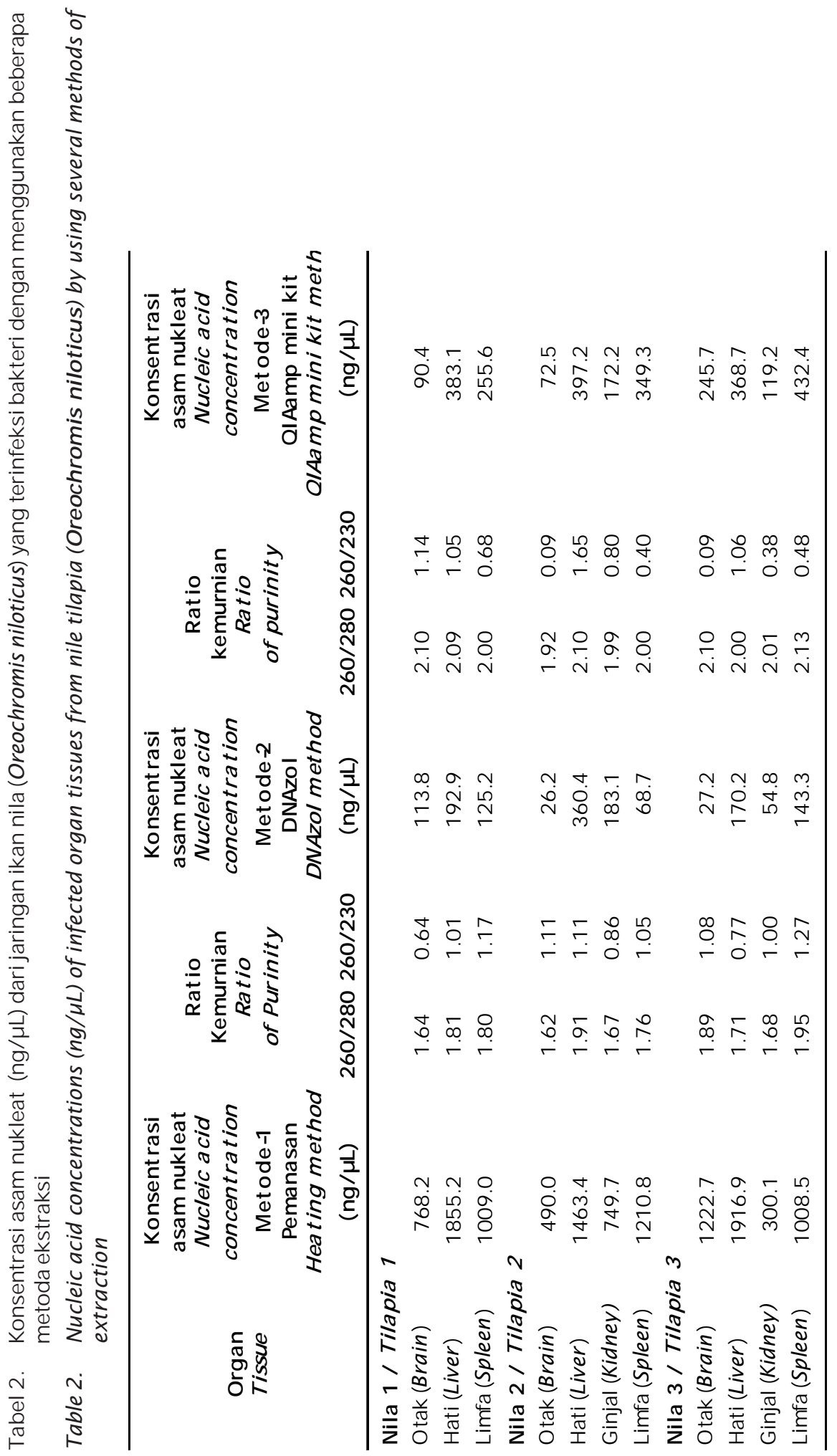


menghasilkan DNA yang lebih bersih dengan tingkat kemurnian yang tinggi. Isolasi langsung dari organ mempercepat proses identifikasi bakteri ini. Selanjutnya perlu dilakukan uji sensitivitas dengan mencampur organ terinfeksi dengan organ ikan sehat dengan perbandingan tertentu untuk mengetahui efektivitas metode ekstraksi yang dilakukan langsung pada jaringan dengan tingkat infeksi ringan dan sangat ringan.

\section{DAFTAR ACUAN}

Anonim. 2008. 260/280 and 260/230 Ratios. [terhubung berkala] www.nanodrop.com [21 Maret 2011].

Austin, B. \& Austin, D.A. 1999. Bacterial Fish Pathogens: Disease in Farmed and Wild Fish. In: Bacterial Fish Pathogens: Disease in Farmed and Wild Fish. Ellis Honwood Ltd, p. 13- 15.

Brian, R., Berridge, H.B., \& Paul, F.F. 2001. Streptococcus agalactiae and Streptococcus difficile 16S-23Sintergenic rDNA: genetic homogeneity and species- specific PCR. Veterinary Microbiology, 78(2): 165- 173.

Eldar, A., Frelier, P.F., Assenta, L., Varner, P.W., Lawhon, S., \& Bercovier, H. 1995. Streptococcus shiloi, the name for an agent causing septicemic infection in fish, is a junior synonym of Streptococcus iniae. Int. J. Syst Bacteriol., 45: 840-842.

Evans, J., Klesius, P., Gilbert, P., Shoemaker, C., \& Al- Sarawi, M. 2002. Characterization of B-haemolytic group B Streptococcus agalactiae in cultured seabream, Sparus auratus $\mathrm{L}$. and wild mullet, Liza klunzingeri (Day) in Kuwait. J. Fish Dis., 25: 505- 513.

Holt, J.G., Krieg, N.R., Sneath, P.H.A., Staley, I.T., \& Williams, S.T. 1994. Bergey's Manual of Determinative Bacteriology. Ed ke- 9. Baltimore: William \& Wilkins, p. 3- 6.

Kawamura, Y., Itoh, Y., Mishima, N., Ohkusu, K., Kasai, H., \& Ezaki, T. 2005. High genetic similarity of Streptococcus agalactiae and Streptococcus difficilis: S. difficilis Eldar et al.,1995 is a later synonym of S. agalactiae Lehmann and Neumann 1896 (Approved Lists 1980). International Journal of Systematic Evololutionary Microbioliology, 55: 961- 965.

Kitao, T. 1993. Streptococcal intections. In: Inglis V, Roberts RJ, Bromage NR (eds) Bacterial disease of fish. Blackwell Scientific Publications, Oxford, p. 196- 210.

Klesius, P.H., Shoemaker, C.A., \& Evans, J.J. 2000. Vaccination: A health management practice for preventing diseases caused by streptococcus in tilapia and other cultured fish. In J. Carvalho, editor. Fifth International Symposium on Tilapia Aquaculture. International, Rio de Janeiro, Brazil, p. 558- 564.

Leninger, A.L. 1975. Biochemistry, 2nd ed., Worth Publishers, New York, p. 859- 890.

Mata, A.I., Gibello, A., Casamayor, A., Blanco, M. M., Domínguez, L., \& Fernández- Garayzábal, J.F. 2004. Multiplex PCR assay for detection of bacterial pathogens associated with warm- water streptococcosis in fish. Applied and Environmental Microbiology, 70: 3183- 3187.

Rasheed, V., Limsuwan, C., \& Plumb, J. 1985. Histopathology Responsible Subject Editor: T: P F! Evelyn, Nanaimo, B.C., Canada of bullminnows, Fundulus grandis Baird and Girard, infected with a non-haemolytic group B Streptococcus sp., J. Fish Dis., 8: 65- 74.

Sjobring, J.H., Mecklenburg, M., Andersen, A.B., \& Miorner, H. 1990. Polymerase chain reaction for detection of Mycobacterium tuberculosis. J. Clin Microbiol., 28: 2200- 2204.

William, Wilfinger, W., Mackey, K., \& Piotr Chomczynski. 1997. Effect of $\mathrm{pH}$ and Ionic Strength on the Spectrophotometric Assessment of Nucleic Acid Purity: BioTechniques, 22: 474- 481. 